Sources of groundwater nitrate revealed using residence time and isotope methods

K. B. Moore, B. Ekwurzel, B. K. Esser, G. B. Hudson, J. E. Moran

October 8, 2004

Applied Geochemistry 
This document was prepared as an account of work sponsored by an agency of the United States Government. Neither the United States Government nor the University of California nor any of their employees, makes any warranty, express or implied, or assumes any legal liability or responsibility for the accuracy, completeness, or usefulness of any information, apparatus, product, or process disclosed, or represents that its use would not infringe privately owned rights. Reference herein to any specific commercial product, process, or service by trade name, trademark, manufacturer, or otherwise, does not necessarily constitute or imply its endorsement, recommendation, or favoring by the United States Government or the University of California. The views and opinions of authors expressed herein do not necessarily state or reflect those of the United States Government or the University of California, and shall not be used for advertising or product endorsement purposes. 


\section{Sources of Groundwater Nitrate Revealed Using Residence Time and Isotope Methods}

Keara B. Moore ${ }^{\dagger}$, Brenda Ekwurzel ${ }^{\dagger}$, Brad K. Esser ${ }^{\ddagger}$, G. Bryant Hudson ${ }^{\star}$, Jean E. Moran ${ }^{* *}$

${ }^{\dagger}$ University of Arizona, Department of Hydrology and Water Resources, 1133 E. North

Campus Dr., Tucson, AZ, 85712, and Lawrence Livermore National Laboratory, 7000

East Ave., Livermore, CA 94550

*email: moran10@1lnl.gov

fax: $\quad 925-422-3160$

Nitrate concentrations approaching and greater than the maximum contaminant level (MCL) are impairing the viability of many groundwater basins as drinking water sources. Nitrate isotope data are effective in determining contaminant sources, especially when combined with other isotopic tracers such as stable isotopes of water and tritium-helium ages to give insight into the routes and timing of nitrate inputs to the flow system. This combination of techniques is demonstrated in Livermore, CA, where it is determined that low nitrate reclaimed wastewater predominates in the northwest, while two flowpaths with distinct nitrate sources originate in the southeast. Along the eastern flowpath, $\delta^{15} \mathrm{~N}$ values greater than $10 \%$ indicate that animal waste is the primary source. Diminishing concentrations over time suggest that contamination results from historical land use practices. The other flowpath begins in an area where rapid recharge, primarily of lownitrate imported water (identified by stable isotopes of water and a tritium-helium 
residence time of less than 1 year), mobilizes a significant local nitrate source, bringing groundwater concentrations up to $53 \mathrm{mg} \mathrm{NO}_{3} \mathrm{~L}^{-1}$. In this area, artificial recharge of imported water via local arroyos increases the flux of nitrate to the regional aquifer. The low $\delta^{15} \mathrm{~N}$ value (3.1\%o) in this location implicates synthetic fertilizer. In addition to these anthropogenic sources, natural nitrate background levels between 15 and $20 \mathrm{mg} \mathrm{NO}_{3} \mathrm{~L}^{-1}$ are found in deep wells with residence times greater than 50 years.

\section{INTRODUCTION}

Nitrate contamination of groundwater is a growing concern for drinking water supplies in many areas in the United States. Between 1993 and 2000, the U.S. Geological Survey's National Water-Quality Assessment program found that 9\% of domestic supply wells and 2\% of public supply wells exceeded the Environmental Protection Agency's maximum contaminant level (MCL) for drinking water of $45 \mathrm{mg}$ $\mathrm{NO}_{3} \mathrm{~L}^{-1}\left(10 \mathrm{mg} \mathrm{L}^{-1}\right.$ as N; Nolan et al., 2002). The California Department of Health Services reports that nitrate is the most common contaminant found in state groundwater and presents a serious threat to the groundwater supply (California Department of Health Services, 2004). In many groundwater basins, urbanization has created a growing demand for drinking water, while long histories of agricultural activity have left aquifers potentially at risk from nitrate.

Water agencies and regulators can develop more effective management strategies when nitrate sources are well understood. Many past studies have used ${ }^{15} \mathrm{~N}$ and ${ }^{18} \mathrm{O}$ in nitrate as tracers of the source and fate of contamination (Kendall and Aravena, 2000). This dual isotope technique is sometimes limited by the overlap of source isotope values 
and by the variety of potential processes that affect nitrate (Aravena et al., 1993; Mengis et al., 2001). Successful studies of nitrate behavior and distribution must take into account the many environmental and historical factors that affect nitrate fate and transport (Böhlke and Denver, 1995).

Our purpose is to improve upon traditional nitrate investigation methods that often yield ambiguous interpretations. We apply an integrated analytical approach using multiple lines of evidence to resolve the manifold origins and pathways of nitrate contamination. This approach is demonstrated in Livermore, CA, a city that relies on groundwater for a significant portion of its drinking water, but where MCL exceedances have occurred at 6 of the 13 public supply wells in the contaminated portion of the basin. As in many regions where this approach may be beneficially applied, Livermore has a decades long history of varied nitrate inputs in a complex groundwater system.

Previous studies of Livermore's nitrate problem have estimated nitrate loading from various sources using literature ranges of potential nitrate inputs from these sources (Steinbergs and Wong, 1980; Raines, Melton, and Carella, Inc., 2002). These assessments consider only theoretical calculations of modern inputs and do not account for residual inputs or for the effects of hydrogeology. In our study, we incorporate these factors by interpreting nitrate isotope and concentration data in the context of local hydrogeology and land use history. We consider nitrate interactions along flowpaths and we analyze dissolved gases to determine whether saturated-zone denitrification has taken place. Additionally, other isotopic tracers such as stable isotopes of water and tritiumhelium residence times give valuable insight into the routes and timing of various nitrate contributions to the flow system. 


\section{STUDY SITE}

The Livermore Valley lies $60 \mathrm{~km}$ east of San Francisco in the Diablo Range (Figure 1). It has a semiarid climate with an average annual precipitation of around 45 cm (State of California, 1967), 80\% of which falls between November and March (Rees, 1994). Natural flow in the two principal streams, Arroyo Mocho and Arroyo Las Positas (Figure 1), is mostly runoff from precipitation in the hills. Since 1962, natural flow has been supplemented with imported water brought from the Sacramento-San Joaquin River Delta through the South Bay Aqueduct (SBA). Although the ratio of artificial to natural recharge varies, imported water is generally dominant, making up approximately three quarters of total recharge along Arroyo Mocho in 2003 (Segura, 2004). Water in the basin is managed for conjunctive use of groundwater and surface water by Alameda County Flood Control and Water Conservation District, Zone 7 (Zone 7).

The Livermore Valley Basin has two primary water-bearing formations. The Livermore Formation is a Plio-Pleistocene bedded sandy gravel with thin aquitards of sandy clay. This is overlain by Holocene age alluvial fill deposits of varying thickness, ranging from less than $30 \mathrm{~m}$ thick at the eastern edge to up to $210 \mathrm{~m}$ thick in the west (Figure 1; State of California, 1967; Moran et al., 2002). The water table is typically 3 to $15 \mathrm{~m}$ below the land surface. Water level contours from 2002 are shown in Figure 2. Both layers are water bearing with higher yields observed in the alluvial deposits (State of California, 1967; Sorenson et al., 1984; Moran et al., 2002). Vertical transport between the formations is thought to be limited to areas where the Livermore Formation is in contact with the overlying stream channel deposits along the arroyos. The aquifer is 
unconfined in the east; to the west, a series of clay aquicludes confines the aquifers (State of California, 1967). Surface and subsurface flow within the Livermore Valley tends to be toward the longitudinal axis of the valley from the north and south, and then westward along the longitudinal axis. Surface water flows into Alameda Creek and out of the watershed, while subsurface flow is drawn towards the major municipal well fields in the western basins (State of California, 1967). Through Zone 7's management, water levels have remained relatively constant for the last twenty years, after a period of groundwater overdraft from the 1940's to the early 1970's. The main flowpath follows an alluvial channel up to $90 \mathrm{~m}$ deep (Figure 2; State of California, 1967).

\section{LAND USE HISTORY}

Multiple potential nitrate sources in the Livermore Valley from both past and present land uses make it an ideal setting for a multi-tracer geochemistry approach. Nitrate monitoring programs identified two locations of particular concern as possible origins of contamination. Around the Livermore Wastewater Reclamation Plant (LWRP), treated wastewater is used in irrigation. In the $1980 \mathrm{~s}$, contributions from LWRP were identified as the cause of high levels of nitrate in groundwater in that area (Sylvester, 1983). Subsequently, wastewater treatment methods were upgraded to include a tertiary treatment step that induces denitrification and reduces nutrient concentrations considerably. In 2003, the average monthly nitrate concentration in the applied water was only $4.9 \mathrm{mg} \mathrm{L}^{-1}$ (pers. comm., D. Atkins, LWRP).

The other area of concern is the unincorporated southeast region of the valley (Figure 1). Past monitoring data show that as early as 1980, a nitrate plume originating in 
this location extended at least to the area where most groundwater extraction for drinking water takes place (Figure 1; unpublished data, Zone 7, 2003). A number of possible nitrate contamination sources exist in the southeast. Several reports in the past have implicated septic leachate as a primary nitrate source (Sylvester, 1983; Sorenson et al., 1984; Raines, Melton, and Carella, Inc., 2002). In this unsewered area, approximately 100 residences have septic systems, a number that has not changed significantly in the past 30 years (Raines, Melton, and Carella, Inc., 2002). Another possible source is livestock waste from both modern and historical inputs. For many decades, ending in the early 1970 s, poultry farming was a significant operation in this area. Over the last century, various grazing operations have existed on the grassland to the south and east of this area (Raines, Melton, and Carella, Inc., 2002).

This southeast region also includes vineyards which have increased in acreage over the last several decades to the current area of approximately $8 \mathrm{~km}^{2}$ (Raines, Melton, and Carella, Inc., 2002). Although vineyards tend to use less nitrogen fertilizer than vegetable crops, they can still contribute significant nitrate to groundwater. One recent report found groundwater nitrate concentrations of up to $61.6 \mathrm{mg} \mathrm{L}^{-1}$ beneath grape fields in the San Joaquin Valley, CA (Burow, et al., 1998), while another demonstrated that, even with closely controlled drip irrigation, $67 \%$ to $79 \%$ of fertilizer nitrogen applied to vineyards in the spring remained in the soil at harvest time, available for leaching with winter rains (Hajrasuliha, 1998).

Another possible nitrate source in the valley is that formed from the oxidation of organic nitrogen, naturally found in soil as a result of plant decomposition and microbial activity (Kendall and Aravena, 2000). Natural nitrate concentrations in groundwater 
below temperate region grasslands, unimpacted by anthropogenic activities, are generally below $9 \mathrm{mg} \mathrm{L}^{-1}$ (Edmunds and Gaye, 1997). In arid and semiarid regions where denitrification is unlikely, however, greater amounts of natural nitrate can accumulate in soils and be available for leaching to groundwater (Edmunds and Gaye, 1997; Brenner et al., 2001; Böhlke, 2002). In Livermore's climate and habitat, leguminous vegetation that supports nitrogen-fixing bacteria is an important potential nitrate source. Burr clover and vetch, species that produce between 90 and $200 \mathrm{~kg} \mathrm{ha}^{-1} \mathrm{y}^{-1}$ of nitrate (National Research Council, 1993), thrive in Livermore during warm, wet winters (Steinbergs and Wong, 1980). It is often assumed that nitrate produced by legumes is balanced by denitrification (Steinbergs and Wong, 1980), but in Livermore's dry summer season, it is possible that there is not enough soil moisture to support denitrification of this large quantity of nitrate. A study in a North African region with a similar semiarid climate attributed groundwater nitrate levels as high as $250 \mathrm{mg} \mathrm{L}^{-1}$ to nitrogen fixed by legumes (Edmunds and Gaye, 1997).

\section{METHODS}

\section{Sample Collection}

The thirty-three well sampling locations from 2003 are shown in Figure 2 and described in Table 1. At monitoring wells, samples were taken using a portable submersible pump. At other wells, dedicated well pumps were used. Most ion and isotope samples were filtered in the field with a $0.45 \mu \mathrm{m}$ in-line filter. Nitrate isotope samples were loaded onto anion exchange columns within 24 hours of sampling, and ion analyses were performed within 48 hours of sampling. For dissolved gas analyses of 
nitrogen, oxygen, and argon, samples were collected in 40-mL vials (VWR

TraceClean ${ }^{\mathrm{TM}}$, amber borosilicate; 0.125 -inch septum liner) with no headspace. Samples were stored in coolers on ice and analyzed on the same day as sampled. A 1-L Pyrex bottle with a polypropylene plug seal cap was filled for tritium analysis and a $30-\mathrm{mL}$ clear, French-square type glass bottle with a Qorpak ${ }^{\mathrm{TM}}$ polyseal-lined cap was filled for analysis of stable isotopes of water. Approximately $10 \mathrm{~mL}$ were collected in copper tubes pinched by metal clamps for noble gas samples.

Total organic carbon (TOC) samples and field dissolved oxygen (DO) data were collected at these wells in 2000. TOC samples were collected in $150 \mathrm{~mL}$ amber borosilicate glass, preserved with concentrated $\mathrm{HCl}$, and refrigerated until analysis. Field DO was measured using a Horiba U-22 multi-parameter water quality probe with a flowthrough cell. Uncertainty in DO measurement is $\pm 0.3 \mathrm{mg} / \mathrm{L}$.

\section{Laboratory Methods}

Nitrate isotope samples were analyzed at the Environmental Isotopes Lab at the University of Waterloo. After extraction as silver nitrate (Silva et al., 2000), nitrogen gas for the measurement of $\delta^{15} \mathrm{~N}$ was produced by the sealed tube $\mathrm{Cu} /$ copper oxide method (Kendall and Grim, 1990) and $\mathrm{CO}_{2}$ for measurement of $\delta^{18} \mathrm{O}$ was produced by combustion with graphite. The isotope ratios of these gases were measured on a PRISM isotope ratio mass spectrometer (Flatt and Heemskerk, 1997). $\delta^{15} \mathrm{~N}$ results are reported as per mil relative to AIR and $\delta^{18} \mathrm{O}$ results are referenced to VSMOW. The noble gases ${ }^{3} \mathrm{He},{ }^{4} \mathrm{He}, \mathrm{Ne}, \mathrm{Ar}, \mathrm{Kr}$, and Xe were measured at Lawrence Livermore National Laboratory (LLNL). ${ }^{3} \mathrm{He}$ and ${ }^{4} \mathrm{He}$ were measured on a VG5400 mass spectrometer, Ar was measured using a high-sensitivity capacitive manometer, and $\mathrm{Ne}, \mathrm{Kr}$, and $\mathrm{Xe}$ were measured on a 
quadropole mass spectrometer (Bayer et al., 1989; Beyerle et al., 2000). Tritium was determined by measuring the rate of ${ }^{3} \mathrm{He}$ accumulation after degassing the sample under vacuum (Eaton et al., 2003). Anions and cations were measured by ion chromatography at LLNL on a Dionex IC DX-600 with a precision of $\pm 2.7 \%$ relative standard deviation for nitrate. Oxygen isotopes of water were measured at LLNL using the $\mathrm{CO}_{2}$ equilibration method (Epstein and Mayeda, 1953), with isotope ratio measurements made on a VG PRISM isotope ratio mass spectrometer. Results are reported as per mil with reference to VSMOW and have a precision of $\pm 0.1 \%$. Deuterium was measured at the University of Arizona using a Finnigan Delta S isotope ratio mass spectrometer. Samples were first reacted with $\mathrm{Cr}$ at $750 \mathrm{C}$ in a Finnigan H/Device coupled to the mass spectrometer. Results are reported as per mil with reference to VSMOW and have a precision of $\pm 0.9 \%$. Dissolved nitrogen and argon gases for examination of excess nitrogen were measured at LLNL by membrane inlet mass spectrometry (MIMS) with an SRS RGA200 quadropole mass spectrometer (Kana et al., 1994). TOC was measured using an OI Corporation Model 1010 wet chemical oxidation TIC-TOC analyzer at LLNL. The analytical uncertainty is less than or equal to $0.3 \mathrm{mg} / \mathrm{L}$.

\section{Isotope and Dissolved Gas Techniques}

A variety of nitrate fractionation processes lead to distinctive isotopic signatures for different nitrate sources. As a result, isotope values of nitrogen and oxygen can be useful in identifying the origin of groundwater nitrate. Synthetic fertilizers generally have $\delta^{15} \mathrm{~N}$ values between $-2 \%$ and $+4 \%$ (Kendall and Aravena, 2000). By the time it reaches the groundwater, however, fertilizer nitrogen tends to be enriched by several per mil over the original source, often making it indistinguishable from soil organic nitrogen, 
which tends to have $\delta^{15} \mathrm{~N}$ values of $+3 \%$ o to $+8 \%$ (Brenner, 2001; Karr et al., 2001; Choi et al., 2003). Nitrate from animal waste has higher $\delta^{15} \mathrm{~N}$ values, usually greater than $+10 \%$, and so can often be distinguished from other sources. All animals produce waste with similar $\delta^{15} \mathrm{~N}$ values, though, so isotopes alone are usually not useful in differentiating between human waste and other animal wastes (Kendall and Aravena, 2000).

Oxygen isotope values of nitrate can help clarify source identification, especially to separate nitrate fertilizer input from other sources, which produce nitrate by nitrification of ammonium or organic nitrogen. Nitrate in synthetic fertilizers is derived from atmospheric nitrogen and so is expected to have a $\delta^{18} \mathrm{O}$ value close to the atmospheric value of $+23.5 \%$. Nitrate from other sources tends to have lighter $\delta^{18} \mathrm{O}$ values because the nitrification process incorporates only one oxygen from dissolved atmospheric oxygen and the other two from water (Kendall and Aravena, 2000). Nitrate from ammonium nitrate fertilizers will have $\delta^{18} \mathrm{O}$ values that reflect both processes (Aravena et al., 1993).

Denitrification produces signatures both in the nitrate isotopes and dissolved gas ratios. As denitrification occurs, nitrogen and oxygen isotopes in nitrate from freshwater are typically enriched in a characteristic pattern with a ratio close to 2:1 (Kendall and Aravena, 2000). Saturated zone denitrification can also be identified by the presence of its end product, nitrogen gas dissolved in groundwater in excess of that expected from equilibration with the atmosphere ("excess $\mathrm{N}_{2}$ "). Comparison with dissolved argon distinguishes this excess $\mathrm{N}_{2}$ from the two sources of atmospheric nitrogen, either nitrogen dissolved (1) through equilibration with air, or (2) from excess air, which is the product 
of air bubbles dissolved under pressure. A nitrogen to argon equilibrium solubility ratio can be predicted based on the recharge temperature derived from noble gas data. A trend of potential nitrogen to argon ratios that incorporate excess air can be extended from this initial equilibrium solubility point (Figure 3). A nitrogen to argon ratio that deviated from this excess air trend towards higher nitrogen would indicate excess $\mathrm{N}_{2}$ was present and that denitrification had occurred. Only saturated zone denitrification can be detected using this technique; in the unsaturated zone, the nitrogen gas produced may be lost to the atmosphere or diluted by the large pool of atmospheric nitrogen present there (Vogel et al., 1981; Böhlke and Denver, 1995).

Mean groundwater residence time is calculated using the tritium-helium method. Tritiogenic helium is calculated after correcting for other helium sources: noble gas concentrations and solubility trends define the recharge temperature and allow for estimation of the atmospheric and excess air helium components. These calculations were made assuming complete dissolution of excess air, an assumption that may lead to slight error in the calculated recharge temperature (Aeschbach-Hertig, et al., 2000). Radiogenic ${ }^{3} \mathrm{He}$ produced through sediment $\mathrm{U}$ and Th decay is assumed to have a typical ${ }^{3} \mathrm{He} /{ }^{4} \mathrm{He}$ ratio of $2 \times 10^{-8}$ (Solomon and Cook, 2000; Hudson et al., 2002). These shallow wells show no evidence of the presence of mantle or significant crustal radiogenic helium. The remaining ${ }^{3} \mathrm{He}$ is the result of tritium decay and, along with measured tritium and tritium's known half-life (12.32 y; Lucas and Unterwerger, 2000), can be used to determine the mean time since recharge for the mixture of water in a sample (Schlosser et al., 1989; Solomon and Cook, 2000; Hudson et al., 2002). Groundwater in areas with low recharge can lose tritiogenic ${ }^{3} \mathrm{He}$ through diffusion across the water table 
(Schlosser, 1989), a concern in semi-arid areas like Livermore. In these calculations, we assume that the recharge rate is high enough to limit ${ }^{3} \mathrm{He}$ loss. This assumption is generally justified by the local high rates of artificial recharge but may lead to some underestimation of residence time. The calculated residence times can be most confidently interpreted as representing the time since recharged water remained several meters or more below the soil-water interface. A 'younger' mean residence time represents a higher fraction of recently recharged water. Tritium-free water recharged more than about 50 years ago.

\section{RESULTS AND DISCUSSION}

Nitrate-source data is most successfully interpreted in the context of the constraints that can be placed on the groundwater flow system using conventional hydrogeological data along with other isotopic and geochemical tracers. Nitrate concentrations are highest in the southeast part of the study area, where many of the wells exceed the MCL (Table 1). The contamination extends to the area of major groundwater extraction as shown in the contour map in Figure 1. In conjunction with the estimated flowpaths, this supports the conclusion of past studies that the most significant nitrate contamination originates in the southeastern recharge area. Current and historical data consistently record higher nitrate concentrations in shallow monitoring wells than in deep wells, suggesting a plume with a shallow core. Nitrate concentrations identify the problem regions but are not diagnostic for distinguishing among competing sources or for helping identify historic or contemporary land use practice culpability. The following 
methods illustrate how critical additional insights are gained with each additional isotope and dissolved gas measurement.

\section{Excess Nitrogen}

The possibility of saturated zone denitrification must be considered before any conclusions can be drawn based on nitrate concentrations or nitrate isotope values. Samples for which noble gas data are available have recharge temperatures calculated to be between 11 and $22 \mathrm{C}$ (Table 1). Nearly all nitrogen to argon ratios fall within the general range delineated for these temperatures by equilibrium solubilities and excess air trends, indicating that excess $\mathrm{N}_{2}$ is not present. Although these results do not exclude the possibility of denitrification before transport to the water table, they demonstrate that saturated zone denitrification is not an important process. This result is consistent with low dissolved organic carbon and high dissolved oxygen measurements that indicate an aerobic system with low reduction potential and lack of an electron donor. Groundwater nitrate data, therefore, may be interpreted directly as indicative of nitrate source, without accounting for attenuation or isotopic enrichment due to denitrification along the flowpath.

\section{Groundwater Sources}

We use stable isotopes of water to establish groundwater provenance (Figure 4). The $\delta^{18} \mathrm{O}$ and $\delta^{2} \mathrm{H} 2003$ groundwater data fit into a trendline falling slightly below the Global Meteoric Water Line (Rozanski, 1993) with a slope generally parallel to it, suggestive of a local meteoric water line trend. The nearest station for which long term precipitation data have been collected is in Santa Maria, CA $400 \mathrm{~km}$ to the south (GNIP, 2004). The Livermore well data fall within the general range defined by Santa Maria 
precipitation isotopes, although the Livermore groundwater's $\delta^{18} \mathrm{O}$ and $\delta^{2} \mathrm{H}$ values are somewhat lighter due to its higher elevation and inland location. Adherence to a LMWL without significant deviation provides evidence that this groundwater experienced little evaporation prior to recharge.

These isotopic data are also useful in distinguishing between the three most probable sources of water to the aquifer: modern precipitation, imported South Bay Aqueduct (SBA) water, and ambient groundwater old enough to predate California's history of large-scale water manipulation (Figure 4). Originating mostly at higher elevations in the Sierra Nevada Mountains, SBA water is isotopically lighter than local precipitation. SBA water recharges the aquifer along Arroyo Mocho from April to November and also makes up $95 \%$ of irrigation water and approximately $80 \%$ of domestic water in the area (Segura, 2004). Older ambient groundwater, identified by its lack of tritium, appears at the heavier end of the observed trend. The various mixing fractions of the three possible sources of water are evident in the isotope data, but the large range observed in local precipitation (-14.8 to $-0.3 \% \delta^{18} \mathrm{O}$; pers. comm., T. Rose, LLNL) prevents quantitative determination of the three fractions. In general, local precipitation is a dominant source, and the shallow and proximal wells to Arroyo Mocho (i.e. wells 22B1, 16E4) contain higher fractions of SBA water, while deeper wells (i.e. wells 10Q2, 7P3) have high fractions of older groundwater.

The groundwater flow system can be further constrained by defining the recharge area using tritium-helium residence time data, with the youngest ages representing locations of most recent recharge (Table 1). The shallow wells nearest the arroyo have residence times of less than one year, and other shallow wells have residence times of 
less than ten years. These data suggest diffuse recharge throughout the study area with substantial recharge and relatively rapid groundwater flow along the arroyo. Along the coarse sediments of the alluvial channel, there is a general correlation between midscreen well depth and groundwater mean residence time. Even the deepest alluvial channel well (well 9Q1) has a significantly higher fraction of young water than the tritium-free deep western wells that are protected by a series of clay layers (wells 7P3 and 7R3). The primary sources of modern recharge, SBA water and precipitation, are both very low in nitrate and cannot be directly implicated as nitrate sources (State of California, 2004).

\section{Groundwater Chemistry}

Measurement of additional ion concentrations allows for separation of the nitrate plume into well-defined spatial groups based on differing solute composition. A plot of chloride vs. sulfate shows that data from $71 \%$ of the wells lie along a constant ratio trend, indicating the similarity of water type and ion source in these wells (Figure 5). This main trend includes the wells along the Alluvial Channel Flowpath and south to Arroyo Mocho. A relatively high chloride to sulfate ratio separates two Boundary Flowpath wells, wells $10 \mathrm{Q} 1$ and $15 \mathrm{~J} 2$, from the rest of the wells in that region, which follow the main trend. Ion data from wells around the LWRP wastewater application area form a distinct lower slope trend, establishing that these wells are dominated by a different water source than the rest of the study area. The low ion end member of this LWRP trend is defined by the area's deeper, confined wells. These wells have a chloride to sulfate ratio matching that of the main trend, suggesting that the water source impacting the shallow wells does not reach the lower aquifers. Well 22B1 stands out due to its high sulfate 
levels. After remaining relatively steady for more than 20 years, sulfate concentrations in well 22B1 began rising in 1999, reaching $190 \mathrm{mg} \mathrm{L}^{-1}$ in 2003, nearly four times the earlier level (unpublished data, Zone 7, 2003). Calcium concentrations showed a significant increase at about the same time, suggesting a major land use change, perhaps a change in vineyard fertilization or soil amendment application.

\section{Nitrate Sources}

\section{Applied Wastewater}

In the northwest region around the LWRP, nitrate isotope data confirm that the shallow wells here have a different nitrate source than in the rest of the study area (Figure 6). Shallow nitrate- $\delta^{15} \mathrm{~N}$ values are between $13.0 \%$ and $29.2 \%$, in the range expected for treated wastewater effluent (Jordan et al., 1997; Griggs et al., 2003). The nitrate- $\delta^{18} \mathrm{O}$ values are the highest of all measured samples, consistent with the expected fractionation effects of denitrification, induced by LWRP as a wastewater processing technique. These data signify that irrigation with reclaimed wastewater is the source of this area's distinctive geochemical signature. Water in the deeper wells, unimpacted by irrigation, has nitrate- $\delta{ }^{15} \mathrm{~N}$ values (6.7\% to $8.8 \%$ ) comparable to the other main trend wells. Stable isotopes of water provide further evidence that the confining layers have prevented applied wastewater from reaching the deeper aquifers; water from these aquifers has an isotopic signature suggesting a precipitation source, while samples from the unconfined layer have heavier $\delta^{2} \mathrm{H}$ and $\delta^{18} \mathrm{O}$ values, likely the result of fractionation during wastewater processing.

Although this LWRP region was identified as a high nitrate source area in the past (Sylvester, 1983), most of the wells currently have nitrate concentrations well below the 
MCL (Table 1). The one well within the area of wastewater application for which long term historical data are available, well 2R1, shows concentrations as high as $75 \mathrm{mg} \mathrm{L}^{-1}$ in the late 1970s. After modernization of treatment facilities in 1981, nitrate levels began to drop, reaching concentrations around $10 \mathrm{mg} \mathrm{L}^{-1}$ in the space of just five years. This demonstrates that the new wastewater treatment methods have been successful at reducing nitrogen loading to the aquifer from reclaimed water irrigation.

\section{Manure}

The southeastern region has been identified as the starting point of the high concentration plume. Although the potential nitrate contamination sources are the same for all of the wells in this area, the ionic composition of wells 15J2 and 10Q1 stands out from the rest (Figure 5). The more northerly Boundary Flowpath on which these wells lie is likely impacted by a different primary nitrate source than the rest of the valley (Figure 2). Measured nitrate- $\delta^{15} \mathrm{~N}$ values greater than $10 \%$ identify animal or human waste as the nitrate source in these wells, but these isotope data do not distinguish between these two inputs. Examining observed historical trends provides further insight. Time series reconstructions of past nitrate concentrations at these wells show that both have had a trend of significantly decreasing nitrate concentrations for at least twenty years (Figure 7). Current nitrate concentrations at both wells are less than a third of peak values and are nearly at the MCL. Although some modern nitrate sources may remain, it seems that a major source has been discontinued or significantly diminished. Because septic and fertilizer input in this area have remained steady or have increased over the last few decades, historical livestock waste (most active inputs approximately 1950 to 1975) is implicated as a major contributor to nitrate contamination along this flowpath. 
Tritium-helium mean residence times of 4 and 9 years in wells 10Q1 and 15J2 demonstrate rapid recharge in this manure-impacted area. As discussed above, however, the contamination in this water comes from sources that were present at the land surface decades ago. This describes a situation in which historical contamination stored in the vadose zone is being flushed into the groundwater over time. This rapid flow and historically-sourced nitrate contamination affects only the shallow part of the aquifer; well 10Q2, $80 \mathrm{~m}$ deeper than well 10Q1, had a nitrate concentration of $16.2 \mathrm{mg} \mathrm{L}^{-1}$, compared to $60.2 \mathrm{mg} \mathrm{L}^{-1}$ in the shallow well. No tritium was detected in well 10Q2, indicating that water at this depth is greater than 50 years old. The sum of the evidence therefore suggests limited vertical flow and little interaction between the upper and lower aquifers in this area of thin alluvial fill.

\section{Fertilizer and Soil Organic Nitrogen}

To supplement nitrate-source information provided by nitrate concentration and isotope data, historical ion data combined with residence time measurements yield critical information regarding the impacts of natural background processes versus the impacts of past or present anthropogenic processes. It is constructive to consider data grouped by the depth of the wells and the hydrogeological layers they tap rather than by geographic location alone. The main trend identified by the anion data, which covers a wide area where diffuse recharge and discharge (pumping) complicate the flow system, is considered as two groups (Figures 2, 5). In one group, wells either pump from aquifers confined beneath several aquicludes or else are predominantly screened at depths greater than $80 \mathrm{~m}$. Three deep wells with tritium concentrations of less than $1 \mathrm{pCi} / \mathrm{L}$ (wells 7P3, 7R3, and 10Q2) provide an archive of groundwater that recharged before major inputs of 
non-natural nitrate. At these wells, groundwater is not impacted significantly by the shallow zone contamination, suggesting that the nitrate detected here represents a natural background. Yet nitrate concentrations in these wells are between $15 \mathrm{mg} \mathrm{L}^{-1}$ and $20 \mathrm{mg}$ $\mathrm{L}^{-1}$, which is higher than generally expected for nitrate from non-anthropogenic sources (Nolan, 2002). As discussed above, this result can be explained by nitrogen-fixing vegetation in Livermore's semi-arid climate. Nitrate- $\delta^{15} \mathrm{~N}$ values between $6.3 \%$ and 7.6\% support the hypothesis of soil organic nitrogen as a natural nitrate source. Other deep wells produce groundwater that is a mixture of tritiated water with high nitrate values and water recharged more than 50 years ago, which likely dilutes the nitrate concentration to some extent. Deeper penetration of younger water in these wells is the result of the influence of pumping patterns and of location with respect to the arroyo and to overlying alluvial fill.

The rest of the samples fitting the main anion trend are found in wells that draw primarily from the top alluvial layer. This group includes all wells along the flowpath following the central alluvial channel plus the shallow wells between this channel and Arroyo Mocho (Figure 2). The Alluvial Channel Flowpath follows roughly the same course as the nitrate plume originating in the southeast. In contrast to the Boundary Flowpath that also originates in that area, nitrate concentrations in wells along the alluvial channel have been steady or rising throughout the last few decades. Well 9Q4 is representative of the alluvial channel wells in the shallow zone of the aquifer. Nitrate levels there averaged around $65 \mathrm{mg} \mathrm{L}^{-1}$ for two decades until a moderate decline was observed over the last five years (Figure 7). In the deeper alluvial channel wells, nitrate levels have been increasing slowly, so that even the deepest well (9Q1) has recently 
surpassed the MCL (Figure 7). This supports the depiction of a separate nitrate source along this flowpath and suggests a source with continuing input rather than a historical source.

Well 22B1 is particularly useful in providing the chemical and isotopic signature of the contaminated alluvial channel end-member, since it is situated at the head of the source area, has a high nitrate concentration, and produces very recently recharged groundwater. This well is at the southeastern perimeter of the nitrate contamination plume and adjacent to Arroyo Mocho (Figure 2). Multi-tracer data reveal unusual conditions in this area that provide important insight into the origin of the contamination. Well 16E4 is another shallow well adjacent to the arroyo but several $\mathrm{km}$ to the west of well 22B1. Light stable isotopes of water at both wells indicate that they draw the majority of their water from recharge of SBA water along the arroyo (Table 1). Tritiumhelium residence times of less than one year at both wells also indicate that rapid recharge from the arroyo is a significant source of shallow groundwater proximal to the arroyo. These wells experience high recharge from the nearby arroyo, in which flow is maintained year round. Potential error in the calculated residence time due to ${ }^{3} \mathrm{He}$ diffusion loss is therefore minimal. Despite this evidence that these two wells have the same source of water, their observed nitrate concentrations are very different. Well 16E4 generally has less than $10 \mathrm{mg} \mathrm{L}^{-1} \mathrm{NO}_{3}$ while well 22B1 historically fluctuates between 30 $\mathrm{mg} \mathrm{L}^{-1}$ and $80 \mathrm{mg} \mathrm{L}^{-1} \mathrm{NO}_{3}$ (unpublished data, Zone 7, 2003). SBA water contributes little nitrate, with an average concentration over the last 10 years of $2.5 \mathrm{mg} \mathrm{L}^{-1}$ (State of California, 2004). To reach the high nitrate levels seen at 22B1, then, recharge through the arroyo must mobilize a local source of nitrate in its short travel time to the well. This 
represents a substantial amount of nitrogen moving through the system, and must either be supplied by a large reserve stored in the soil or vadose zone or by a source that is continually being replenished. Either a soil or fertilizer source, therefore, is implicated as the source of nitrate in this location.

All nitrate concentrations measured in the alluvial region were greater than $33 \mathrm{mg}$ $\mathrm{L}^{-1}$ and $\delta^{15} \mathrm{~N}$ values were less than $8 \%$ (Figure 6). Well 22B1 and well 15G4 have high nitrate concentrations, 53.1 and $53.8 \mathrm{mg} \mathrm{L}^{-1}$, and are in the high end of the isotope range expected for synthetic fertilizer (3.1\%o and 4.8\%o nitrate- $\delta{ }^{15} \mathrm{~N}$ values, respectively). This also overlaps the low end of the range for nitrate from reduced soil nitrogen, another potential source given these wells' location downgradient of vineyards and grassland. Although nitrogen isotopes alone cannot distinguish between these two sources, it is unlikely that concentrations as high as $80 \mathrm{mg} \mathrm{L}^{-1}$, which have been measured at well 22B1, result from soil nitrogen inputs alone. As groundwater flows from the southeast to the northwest along the Alluvial Channel Flowpath, the trend, originating at well 22B1, is towards decreasing nitrate concentrations and increasing $\delta^{15} \mathrm{~N}$ values (Figure 6). In the absence of denitrification, remineralizing nitrate in the soil and mixing with uncontaminated water would result in such a trend toward decreased nitrate concentrations and increasing nitrate- $\delta^{15} \mathrm{~N}$ values into the range expected for soil nitrogen (Choi, 2003).

Nitrate- $\delta{ }^{18} \mathrm{O}$ data provide further evidence for a fertilizer source of nitrate in this area. Wells $22 \mathrm{~B} 1,15 \mathrm{G} 4$, and $15 \mathrm{G} 5$ have nitrate- $\delta^{18} \mathrm{O}$ values between $8.1 \%$ and $10.9 \%$ o (Table 1), relatively high compared to the values found at the other shallow wells with low $\delta^{15} \mathrm{~N}$, which range from $2.8 \%$ to $4.8 \%$ nitrate- $\delta^{18} \mathrm{O}$. High nitrate- $\delta^{18} \mathrm{O}$ is consistent 
with a synthetic fertilizer nitrate source. Nitrate from synthetic fertilizer generally has a nitrate- $-\delta^{18} \mathrm{O}$ value around $23 \%$ (Kendall and Aravena, 2000), while ammonium nitrate fertilizer, with approximately $50 \%$ of its oxygen from fertilizer nitrate and $50 \%$ from nitrified fertilizer ammonium, would be expected to have a nitrate- $\delta^{18} \mathrm{O}$ value of approximately $13 \%$ in this environment (Aravena et al., 1993).

\section{CONCLUSIONS}

In this study, the separation of nitrate sources introduced decades ago is made possible by a multiple-analysis approach using current and historical data. Stable isotopes provide information about water sources, while tritium-helium age dating defines groundwater residence times and transport behavior. In addition, dissolved gas and nitrate isotope evidence indicate that nitrate moves conservatively in the groundwater, which simplifies source attribution. Nitrate isotope measurements are then combined with information about land use history to identify contaminant sources. Based on this data, several flowpaths originating in the southeastern region were identified, one primarily impacted by historical manure sources and the other with a significant modern synthetic fertilizer component. This integrated approach reveals a much larger role for fertilizer and natural soil nitrogen than suggested by prior assessments, which used source mass and plume delineation methods to attribute most of the contamination to septic tanks and livestock. In addition to identifying contaminant sources, these methods offer a deeper understanding of how the severity and extent of contamination is affected by hydrogeology and groundwater management practices. In this case, the nitrate problem is amplified by artificial recharge in the source area, a 
region where the aquifer is vulnerable because it is unconfined and experiences high vertical recharge. This approach can be widely applied to other regions with historical nitrate inputs and can provide valuable information to water managers in evaluating future mitigation strategies.

Acknowledgements - Additional support for this work has been provided by Sustainability of semi-Arid Hydrology and Riparian Areas (SAHRA), the California State Water Resources Control Board Groundwater Ambient Monitoring and Assessment Program, and by the Glenn T. Seaborg Institute's Nuclear Science Internship Program at LLNL. We thank Gail Eaton and Max Hu of LLNL, Chris Eastoe of the University of Arizona's Department of Geosciences, and the University of Waterloo's Environmental Isotope Laboratory for laboratory analyses. We thank Zone 7 personnel, in particular Colleen Winey and David Lunn, for assisting with collection of field samples and for sharing data and information about local hydrogeology.

This work was performed under the auspices of the U.S. Department of Energy by University of California, Lawrence Livermore National Laboratory under contract W-7405-Eng-48. 


\section{REFERENCES}

Aeschbach-Hertig, W.; Peeters, F.; Beyerle, U.; Kipfer, R. Palaeotemperature reconstruction from noble gases in ground water taking into account equilibration with entrapped air. Nature 2000, 405, 1040-1044.

Aravena, R.; Evans, M. L.; Cherry, J. A. Stable isotopes of oxygen and nitrogen in source identification of nitrate from septic systems. Ground Water 1993, 31(2), 180-186.

Bayer, R.; Schlosser, P.; Bönisch, G.; Rupp, H.; Zaucker, F.; Zimmek, G. Performance and blank components of a mass spectrometric system for routine measurement of helium isotopes and tritium by the ${ }^{3} \mathrm{He}$ ingrowth method., 5, pp., Sitzungsberichte der Heidelberger Akademie der Wissenschaften Mathematisch-naturwissenschaftliche Klasse, Berlin, 1989.

Beyerle, U.; Aeschbach-Hertig, W.; Imboden, D. M.; Baur, H.; Graf, T.; Kipfer R. Amass spectrometric system for the analysis of noble gases and tritium from water samples. Env. Sci. Technol. 2000 34(10), 2042-2050.

Böhlke, J. K.; Denver, J. M. Combined use of groundwater dating, chemical, and isotopic analyses to resolve the history and fate of nitrate contamination in two agricultural watersheds, Atlantic coastal plain, Maryland. Water Resour. Res. 1995, 31, 2319-2339.

Böhlke, J.K. Groundwater recharge and agricultural contamination. Hydrogeol. J. 2002, $10,153-179$. 
Brenner, D. L.; Amundsen, R.; Baisden, T.; Kendall, C.; Harden, J. Soil N and 15N variation with time in a California annual grassland ecosystem. Geochim. Cosmochim. Acta 2001, 65, 4171-4186.

Burow, K. R.; Shelton, J. L.; Dubrovsky, N. M. Occurrence of nitrate and pesticides in ground water beneath three agricultural land-use settings in the eastern San Joaquin Valley, California, 1993-1995: U.S. Geological Survey Water Resource Investigation Report 97-4284; U.S. Geological Survey: Sacramento, 1998.

California Department of Health Services. Drinking Water: Overview of Monitoring Results 1994-2003, and an Indication of Dominant Contaminants (4/20/04 Update). http://www.dhs.ca.gov/ps/ddwem/chemicals/monitoring/results94-03.htm

Choi, W.-J.; Lee, S.-M.; Ro, H.-M. Evaluation of contamination sources of groundwater nitrate using nitrogen isotope data: A review. Geosci. J. 2003, 7(1), 81-87.

Eaton, G. F.; Hudson, G. B.; Moran, J. E. Tritium-helium-3 age-dating of groundwater in the Livermore Valley of California. Lawrence Livermore National Laboratory. 2003.

Edmunds, W. W.; Gaye, C. B. Naturally high nitrate concentrations in groundwaters from the Sahel. J. Environ. Qual. 1997, 26, 1231-1239.

Epstein, S.; Mayeda, T. Variation of O-18 content of waters from natural sources. Geochim. Cosmochim. Acta 1953, 4, 213-227.

Flatt, H.; Heemskerk, A. R. ${ }^{15} \mathrm{~N}^{18} \mathrm{O}$ in Dissolved Nitrate. Environmental Isotope Laboratory, Department of Earth Sciences, University of Waterloo, 1997. 
Global Network of Isotopes in Precipitation (GNIP) and Isotope Hydrology Information System (ISOHIS). http://ishois.iaea.org (Santa Maria, CA; precipitation; 1962-1976)

Griggs, E. M.; Kump, L. R.; Böhlke, J. K. The fate of wastewater-derived nitrate in the subsurface of the Florida Keys: Key Colony Beach, Florida. Estuar. Coast. Shelf Sci. 2003, 58, 517-539.

Hajrasuliha, S.; Rolston, D. E.; Louie, D. T. Fate of N-15 fertilizer applied to trickleirrigated grapevines. Am. J. Enol. Viticult. 1998, 49, 191-198.

Hudson, G. B.; Moran, J. E.; Eaton, G. F. Interpretation of Tritium-3Helium Groundwater Ages and Associated Dissolved Noble Gas Results from Public Water Supply Wells in the Los Angeles Physiographic Basin Interpretation of Tritium-3Helium Groundwater Noble Gas Results from Public Water Supply Wells in the Los Angeles Physiographic Basin: Report to the California State Water Resources Board. Lawrence Livermore National Laboratory. 2002. http://www.llnl.gov/tid/lof/documents/pdf/245359.pdf

Jordan, M. J.; Nadelhoffer, K. J.; Fry, B. Nitrogen cyclic in forest and grass ecosystems irrigated with $15 \mathrm{~N}$ enriched wastewater. Ecol. Appl. 1997, 7, 864-881.

Kana, T. M.; Darkangelo, C.; Hunt, M. D.; Oldham, J. B.; Bennett, G. E.; Cornwell, J. C. Membrane inlet mass spectrometer for rapid high-precision determination of nitrogen, oxygen, and argon in environmental water samples. Anal. Chem. 1994, 66, 4166-4170. 
Karr, J. D.; Showers, W. J.; Gilliam, J. W.; Andres, A. S. Tracing nitrate transport and environmental impact from intensive swine farming using delta N-15. J. Environ. Qual. 2001, 30, 1163-1175.

Kendall, C.; Grim, E. Combustion tube method for measurement of nitrogen isotope ratios using calcium oxide for total removal of carbon dioxide and water. Anal. Chem. 1990, 62, 526-529.

Kendall, C.; Aravena, R. Nitrate Isotopes in Groundwater Systems. In Environmental Tracers in Subsurface Hydrology; Cook, P. G., Herczeg, A. L., Eds.; Kluwer Academic Publishers: Norwell, Massachusetts, 2000; pp 261-297.

Lucas, L. L.; Unterwerger, M. P. Comprehensive review and critical evaluation of the half-life of tritium. Journal of Research of the National Institute of Standards and Technology 2000, 105, 541-549.

Mengis, M.; Walther, U.; Bernasconi, S. M.; Wehrli, B. Limitations of using d18O for the source identification of nitrate in agricultural soils. Env. Sci. Technol. 200135 (9), 1840-1844.

Moran, J. E.; Hudson, G. B.; Eaton, G. F.; Leif, R. A contamination vulnerability assessment for the Livermore-Amador and Niles Cone groundwater basins, California State Water Resources Control Board, 2002.

Morse, J.W.; Mackenzie, F. T. Geochemistry of Sedimentary Carbonates, Developments in Sedimentology 48, Elsevier, Amsterdam, 1990; pp. 295-309. 
National Research Council, Committee on Long-Range Soil and Water Conservation, Board of Agriculture. Soil and water quality: An agenda for agriculture; National Academy Press: Washington, D.C., 1993.

Nolan, B. T.; Hitt, K. J.; Ruddy, B. C. Probability of nitrate contamination of recently recharged groundwaters in the conterminous United States. Environ. Sci. Technol. 2002, $36,2138-2145$.

Parkhurst D. L.; Appelo C. A. J. User's Guide to PHREEQC (Version 2) - A Computer Program for Speciation, Batch Reaction One-Dimensional Transport, and Inverse Geochemical Calculations: U.S. Geological Survey Water Resource Investigation Report 99-4259; U.S. Geological Survey: Denver, 2002.

Raines, Melton, and Carella, Inc. Groundwater Nitrate Sources in the Buena Vista Area. Report to Alameda County Flood Control and Water Conservation District, Zone 7, 2002.

Rees, G. R. Tracing ground water movement in the eastern Livermore Valley, Alameda County, California, using stable isotopes, major ion chemistry, and a line source model. Lawrence Livermore National Laboratory. 1994.

Rozanski, K. L.; Araguas-Araguas, L.; Gonfiantini, R. Isotopic patterns in modern global precipitation. In Climate Change in Continental Isotopic Records, Geophysical Monograph 78; Swart, P. K.; McKenzie, J.; Lohmann. K. C.; Savin, S. Eds.; American Geophysical Union: Washington, D.C., 1993; pp1-36.

Schlosser, P.; Stute, M.; Sontag, C.; Munich, K. O. Tritiogenic ${ }^{3} \mathrm{He}$ in shallow groundwater. Earth Planet. Sci. Lett. 1989, 94, 245-256. 
Segura, S. Main Basin Groundwater Hydrologic Inventory, 1974 - 2003. Memorandum to Water Resources Manager, Alameda County Flood Control and Water Conservation District, Zone 7, 2004. http://www.zone7water.com/reports.html

Silva, S. R.; Kendall, C.; Wilkison, D. H.; Ziegler, A. C.; Chang, C. C. Y.; Avanzino, R. J. A new method for collection of nitrate from fresh water and the analysis of nitrogen and oxygen isotope ratios. $J$. Hydrol. 2000, 228, 22-36.

Solomon, D. K.; Cook, P. G. 3H and 3He. In Environmental Tracers in Subsurface Hydrology; Cook, P. G., Herczeg, A. L., Eds.; Kluwer Academic Publishers: Norwell, Massachusetts, 2000; pp 397-424.

Sorenson, S. K.; Cascos, P.V.; Glass, R. L. Water-quality conditions and an evaluation of ground-and surface-water sampling programs in the Livermore-Amador Valley, California: U.S. Geological Survey Water Resources Investigation Report 84-4352; U.S. Geological Survey: Sacramento, 1984.

State of California, Department of Water Resources. Bulletin No. 118-2: Livermore and Sunol Valleys, Evaluation of ground water resources; Appendix A, Geology. 1967.

State of California, Department of Water Resources, Water Data Library, Water Quality Data. http://wdl.water.ca.gov/wq/gst/water_quality_report1_gst.asp (Station: Banks, County: Alameda, Dates: 9/93 to 9/03.) Accessed June, 2004.

Steinbergs, C.; Wong, V. Preliminary Assessment of Nitrate-Nitrogen Loading Agents and Removal Mechanisms Impacting Local Ground Waters Within the Livermore - 
Amador Valley of California, Zone 7, Alameda County Flood Control and Water Conservation District, 1980.

Sylvester, M.A. Land application of wastewater and its effect on ground-water quality in the Livermore-Amador Valley, Alameda County, California: U.S. Geological Survey Water Resources Investigation Report 82-4100; U.S. Geological Survey: Sacramento, 1983.

Vogel, J. C.; Talma, A. S.; Heaton, T. H. E. Gaseous nitrogen as evidence for denitrification in groundwater. J. Hydrol. 1981 50, 191-200. 


\section{FIGURES AND TABLES}

Figure 1. Nitrate concentrations in Livermore Valley. Approximate nitrate

contours, in mg/L, kriged using RockWare ${ }^{\text {TM }}$. Based on previous dataset from 2000 except for two points from 2001, included to more accurately delineate the boundary of the contaminated region. All wells have depths less than $35 \mathrm{~m}$, the approximate depth of a non-continuous aquiclude and thus the defined cutoff for the aquifer's shallow zone. The apparent gap in the central valley is an artifact of the limitations of the data, rather than a break in the plume.

Figure 2. 2003 sampling locations. Symbols represent spatial groups referred to in Figures 3 through 5. Main flowpaths, estimated from 2002 water level measurements (shown in inset in meters above mean sea level; C. Winey, Zone 7, pers. comm.), are illustrated with arrows.

Figure 3. Dissolved nitrogen versus dissolved argon. The WEA ("water equilibrated with air") line represents the nitrogen and argon ratio expected based on equilibrium solubilities of the gases. The excess air lines are projected by assuming that excess air is the result of complete dissolution of entrapped air bubbles. All samples fall, within error, on or above the projected region of ratios for dissolved excess air. Any samples above this region likely experienced partial air bubble dissolution during recharge. The one outlier below this region, well 7R3, does not fit a possible denitrification trend and this result can probably be explained as gas loss during sampling. 
Figure 4. Stable isotopes of water. Three potential water sources include South Bay Aqueduct (SBA), modern precipitation, and local groundwater. Trendline represents linear regression of all groundwater data from this study. The inset demonstrates how Livermore well sample data compare to the Global Meteoric Water Line (GMWL) and to precipitation data collected at Santa Maria, CA, the nearest long term monitoring station (GNIP, 2004).
SBA:
$\delta^{18} \mathrm{O}=-10.6 \%$ o to $-9.9 \% ; \delta^{2} \mathrm{H}=-79 \%$ o to $-70 \%$ o
(Rees, 1994)
LLNL Precipitation: $\delta^{18} \mathrm{O}=-7.9 \pm 2.8 \% ; \delta^{2} \mathrm{H}$, unknown
(pers. comm., T. Rose)
Groundwater: $\delta^{18} \mathrm{O}=-7.4 \%$ to $-6.9 \% ; \delta^{2} \mathrm{H}=-53 \%$ to $-49 \%$ o
(Rees, 1994)
GMWL: $\delta^{2} \mathrm{H}=8.17( \pm 0.07) \delta^{18} \mathrm{O}+11.27( \pm 0.65) \%$ (VSMOW)
(Rozanski, 1993)

Figure 5. Chloride vs. sulfate compositions. Three spatially distinct water types have been distinguished. Regions represented by well symbols are defined in Figure 2.

Figure 6. Nitrate concentrations and $\delta^{\mathbf{1 5}} \mathbf{N}$ values in groundwater. Expected $\delta^{15} \mathrm{~N}$ ranges for various sources are identified. Several samples from the wastewater region had $\delta^{15} \mathrm{~N}$ values off the scale of the chart, as indicated. Regions represented by well symbols are defined in Figure 2.

Figure 7. Nitrate concentration time series data. Drinking water maximum contaminant level (MCL) shown for reference. Well depths indicated. (a) Boundary Flowpath. (b) Alluvial Channel Flowpath. 
Table 1. Well data and chemical and isotopic analyses of samples. 


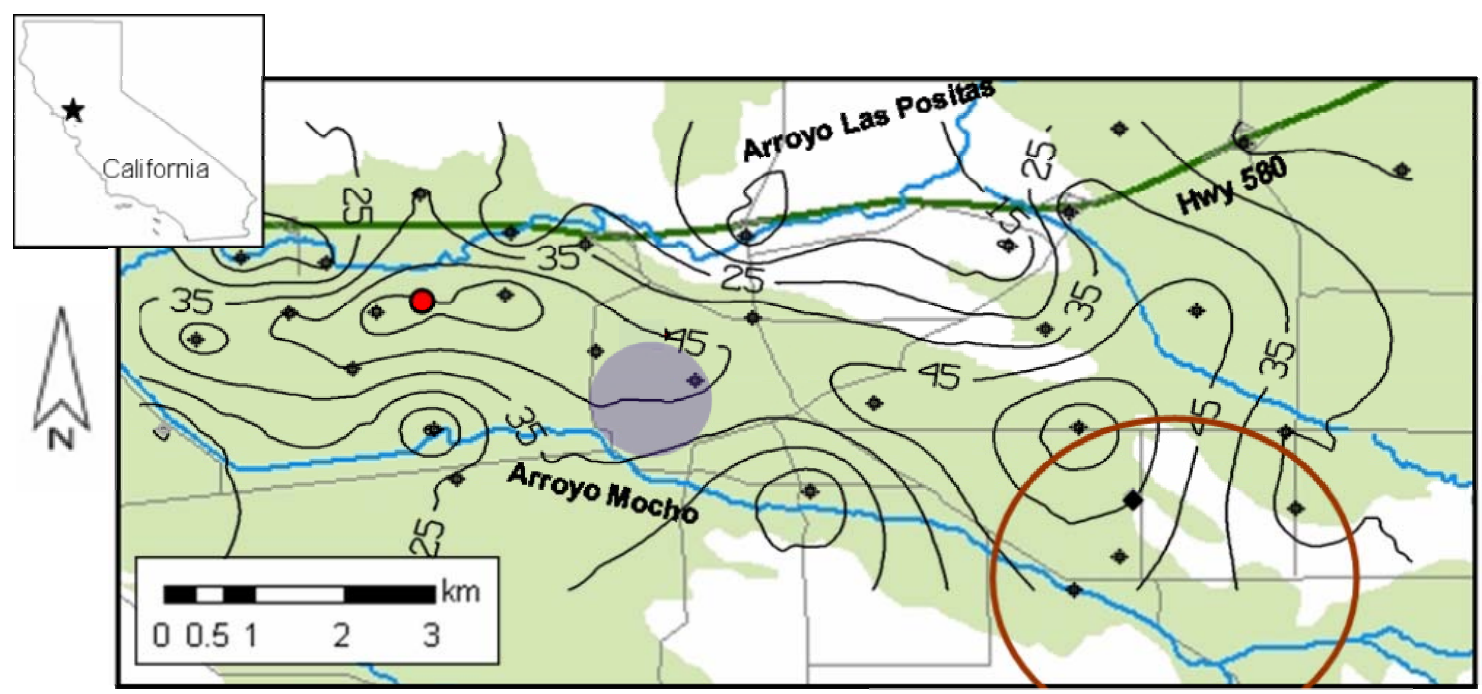

- Well used in nitrate contour

Region of high drinking water extraction Water-bearing alluvial deposits

O Livermore Wastewater Reclamation Plant Multiple nitrate inputs include septic tanks, fertilized vineyards, livestock, and grassland

Figure 1. Nitrate concentrations in Livermore Valley. 


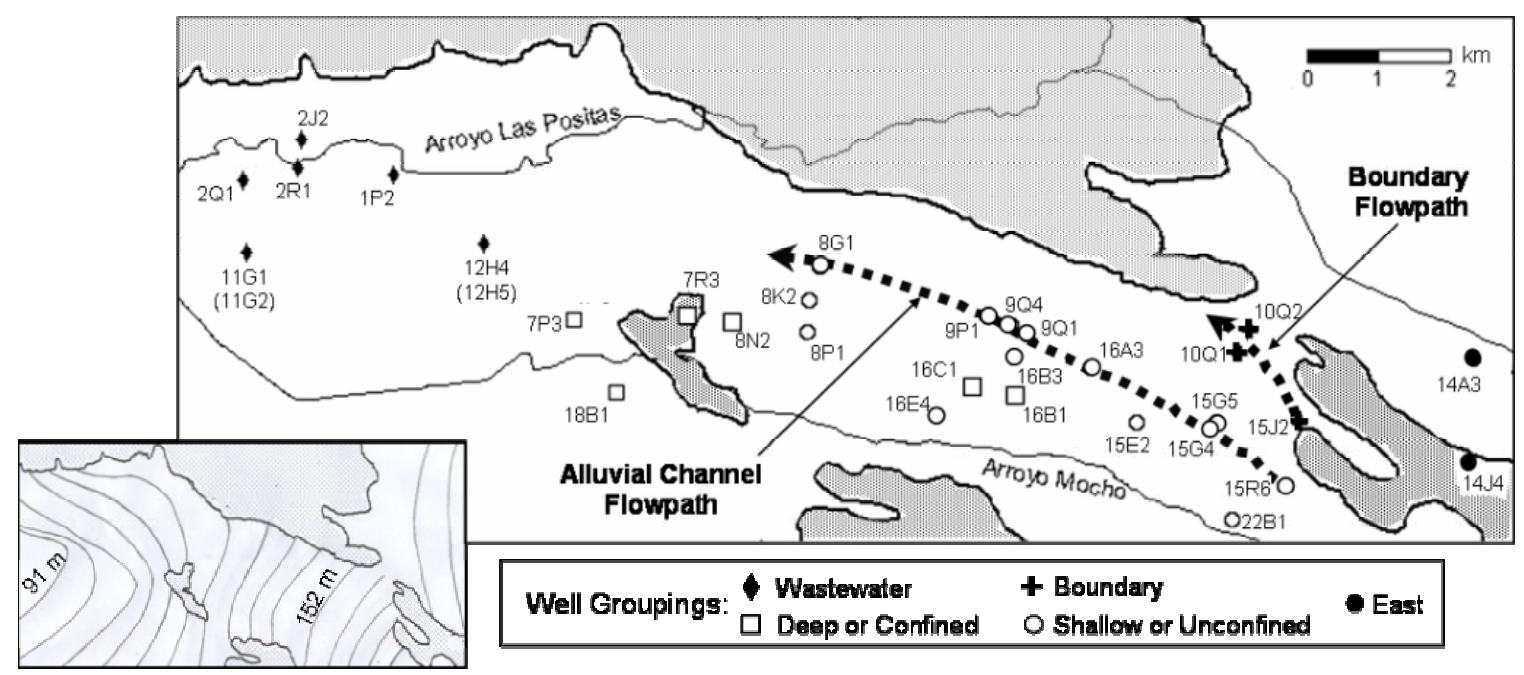

Figure 2. 2003 sampling locations. 


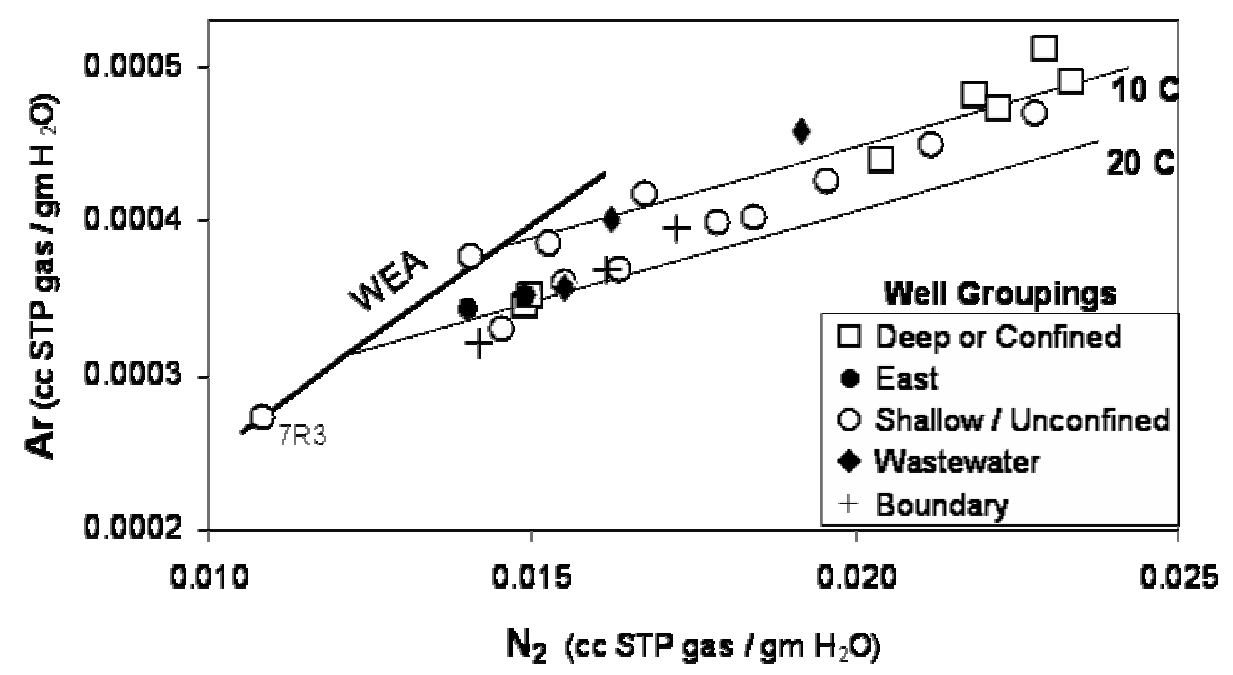

Figure 3. Dissolved nitrogen versus dissolved argon. 


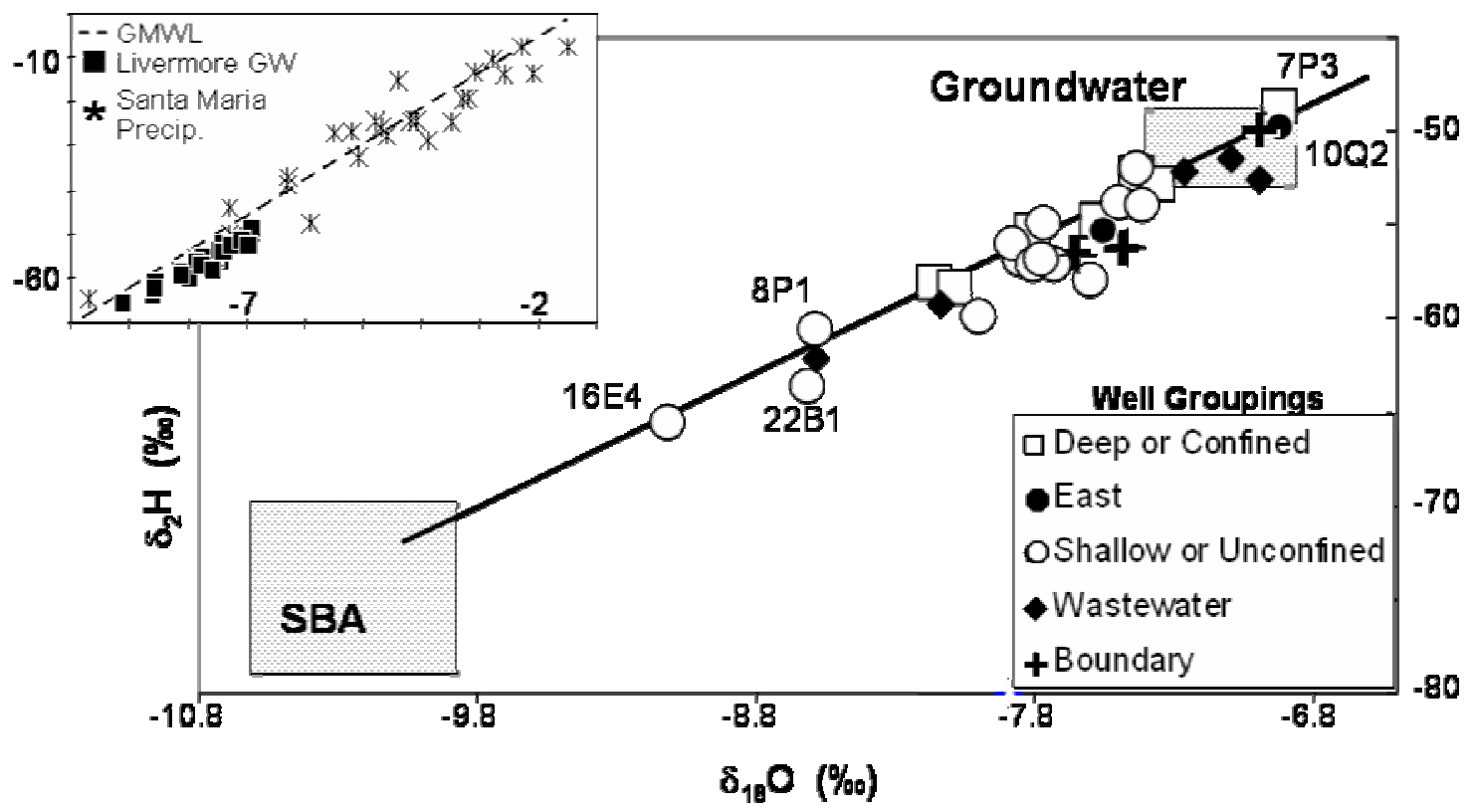

Figure 4. Stable isotopes of water. 


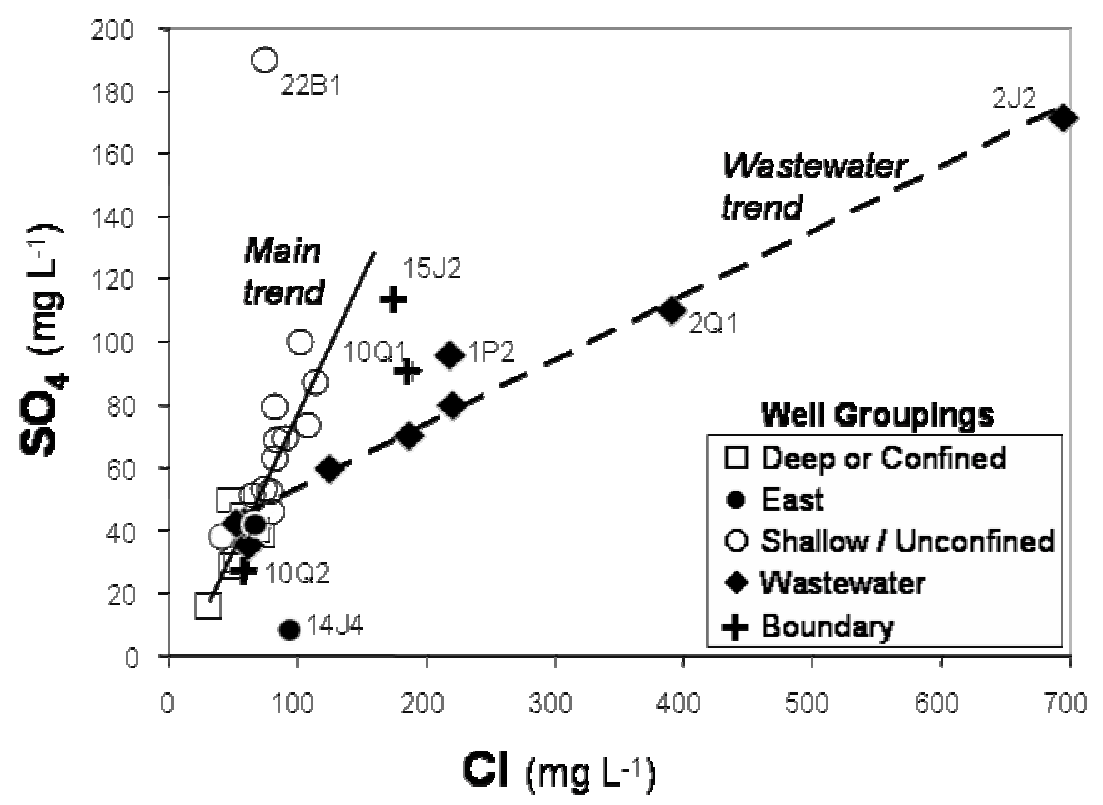

Figure 5. Chloride vs. sulfate compositions. 


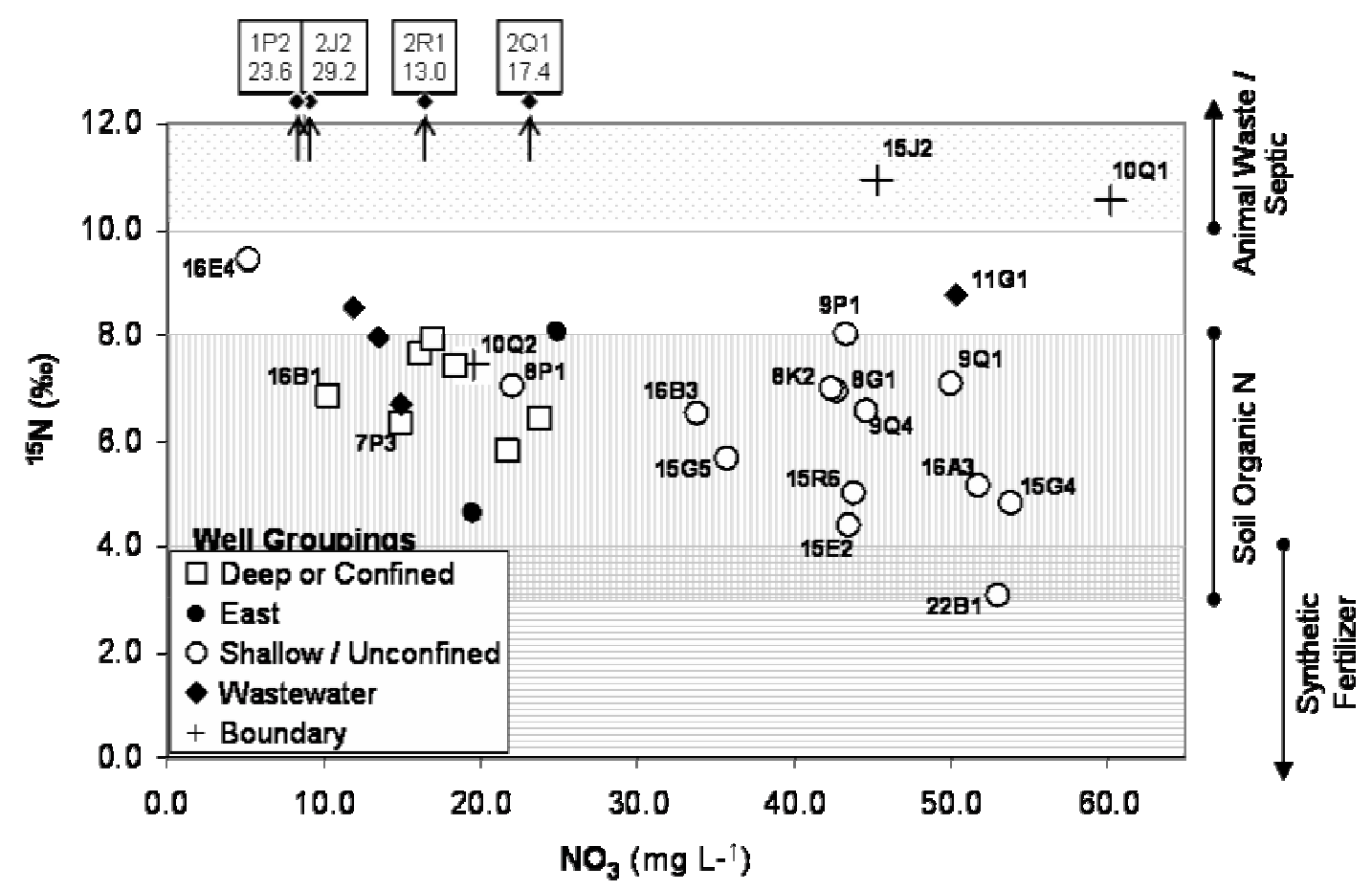

Figure 6. Nitrate concentrations and $\delta^{15} \mathrm{~N}$ values in groundwater. 
a)
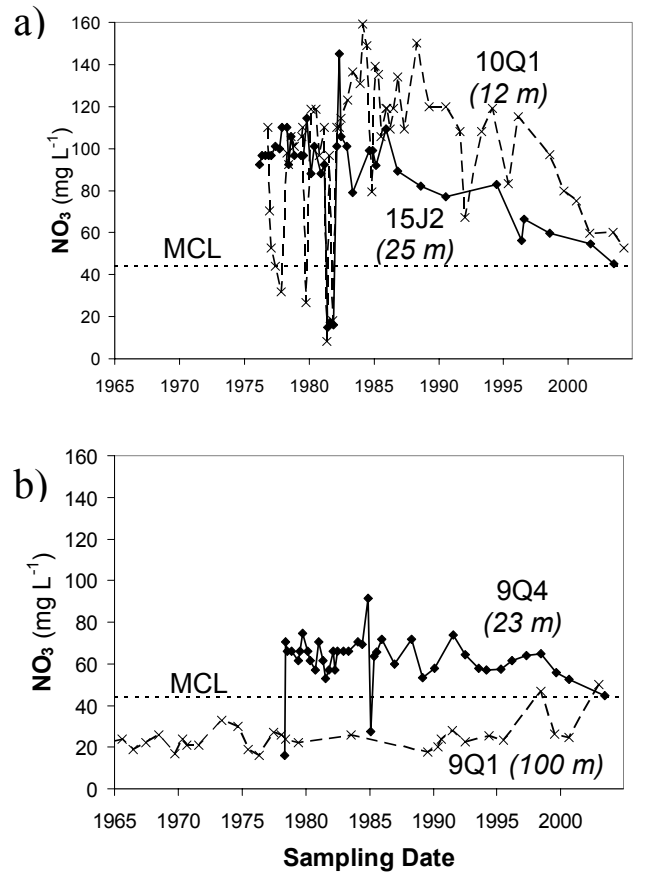

Figure 7. Nitrate concentration time series data. 


\begin{tabular}{|c|c|c|c|c|c|c|c|c|c|c|c|c|}
\hline \multirow{2}{*}{$\begin{array}{c}\text { Well } \\
\text { ID } \\
1 \mathrm{P} 2\end{array}$} & $\begin{array}{l}\text { Well } \\
\text { Type }^{\mathrm{a}}\end{array}$ & \multicolumn{2}{|c|}{$\begin{array}{c}\text { Well Screen }{ }^{\mathrm{b}} \\
\text { m below surface }\end{array}$} & $\begin{array}{l}\mathrm{NO}_{3}{ }^{\mathrm{c}} \\
m g / L\end{array}$ & $\begin{array}{c}\delta^{2} \mathrm{H}^{\mathrm{c}} \\
\left(\mathrm{H}_{2} \mathrm{O}\right) \\
----p e r\end{array}$ & $\begin{array}{c}\delta^{18} \mathrm{O}^{\mathrm{c}} \\
\left(\mathrm{H}_{2} \mathrm{O}\right) \\
\text { mil ------ }\end{array}$ & $\begin{array}{c}{ }^{3} \mathrm{H}^{3} \mathrm{He} \\
\text { age }^{\mathrm{c}} \\
y r\end{array}$ & $\begin{array}{l}\text { Recharge } \\
\text { Temp } \\
{ }^{\circ} \mathrm{C}\end{array}$ & $\begin{array}{l}\delta^{15} \mathrm{~N}^{\mathrm{c}} \\
\left(\mathrm{NO}_{3}\right) \\
----p e r\end{array}$ & $\begin{array}{c}\delta^{18} \mathrm{O}^{\mathrm{c}} \\
\left(\mathrm{NO}_{3}\right) \\
m i l---\end{array}$ & $\begin{array}{l}\mathrm{TOC}^{\mathrm{c}} \\
m g / L\end{array}$ & $\begin{array}{l}\text { Field } \\
\mathrm{DO}^{\mathrm{c}} \\
m g / L\end{array}$ \\
\hline & MW & 12.2 & 13.7 & 8.4 & -53 & -7.0 & 8 & 14.4 & 23.6 & 15.9 & - & 0.3 \\
\hline $1 \mathrm{P} 2$ & MW & same a & above & 8.2 & $-52^{\mathrm{d}}$ & -6.9 & - & - & 23.6 & 14.7 & - & 0.6 \\
\hline $2 \mathrm{~J} 2$ & MW & 9.5 & 12.5 & 8.8 & -51 & -7.1 & - & - & 29.2 & 11.6 & - & 0.4 \\
\hline 2Q1 & MW & 10.7 & 13.7 & 23.3 & -52 & -7.3 & - & - & 17.4 & 11.8 & - & 0.3 \\
\hline 2R1 & MW & 6.4 & 7.9 & 16.6 & $-53^{\mathrm{d}}$ & -7.3 & - & - & 13.0 & 6.7 & - & 0.9 \\
\hline $7 \mathrm{P} 3$ & PS & 131.1 & $149.3^{\mathrm{e}}$ & 15.0 & -49 & -6.9 & $>50$ & 11.8 & 6.3 & 4.0 & 0.36 & - \\
\hline 7R3 & PS & 125.0 & 161.0 & 16.3 & -53 & -7.4 & $>50$ & 15.1 & 7.6 & 6.8 & 0.51 & - \\
\hline $8 \mathrm{G} 1$ & PS & 36.6 & 138.7 & 42.8 & -55 & -7.8 & 21 & 15.7 & 6.9 & 5.2 & 0.45 & - \\
\hline $8 \mathrm{~K} 2$ & MW & 19.5 & 21.0 & 42.5 & -56 & -7.9 & 10 & 19.8 & 7.0 & 3.6 & - & - \\
\hline $8 \mathrm{~N} 2$ & PS & 42.7 & 157.0 & 17.0 & -58 & -8.1 & 14 & 15.8 & 7.9 & 8.1 & 0.52 & - \\
\hline $8 \mathrm{P} 1$ & PS & 37.2 & 80.2 & 22.1 & -61 & -8.6 & 9 & 15.5 & 7.0 & 4.8 & 0.57 & - \\
\hline 9P1 & PS & 58.5 & 150.0 & 43.3 & -52 & -7.4 & 21 & 15.8 & 8.0 & 6.5 & 0.37 & - \\
\hline $9 \mathrm{Q} 1^{\mathrm{f}}$ & PS & 85.4 & $100.6^{\mathrm{e}}$ & 50.1 & -54 & -7.5 & 16 & 15.5 & 7.8 & 11.8 & - & - \\
\hline 9Q4 & MW & 21.3 & 22.9 & 44.7 & -57 & -7.8 & 10 & 17.2 & 65 & 4.4 & 0.71 & - \\
\hline 10Q1 & MW & 10.4 & 11.9 & 60.2 & -56 & -7.5 & 9 & - & 10.5 & 6.6 & 1.30 & 3.2 \\
\hline 10Q2 & MW & 90.9 & 99.1 & 19.6 & -50 & -7.0 & $>50$ & - & 7.4 & 6.6 & 0.20 & - \\
\hline $11 \mathrm{G} 1$ & MW & 30.5 & 33.5 & 50.4 & $-53^{\mathrm{d}}$ & -6.7 & - & - & 8.7 & 3.8 & - & - \\
\hline $11 \mathrm{G} 2$ & MW & 70.1 & 103.7 & 12.0 & $-66^{\mathrm{d}}$ & -8.8 & - & - & 8.5 & 6.0 & - & - \\
\hline $12 \mathrm{H} 4$ & MW & 56.4 & 79.3 & 13.6 & -62 & -8.6 & 7 & 13.1 & 7.9 & 6.0 & - & - \\
\hline $12 \mathrm{H} 5$ & MW & 109.8 & 118.9 & 15.0 & -59 & -8.1 & 12 & - & 6.7 & 8.3 & - & - \\
\hline $14 \mathrm{~A} 3$ & MW & 30.5 & 32.0 & 25.0 & -55 & -7.6 & 5 & 16.9 & 8.1 & 4.7 & - & - \\
\hline $14 \mathrm{~J} 4$ & PV & 30.5 & 71.6 & 19.5 & -50 & -6.9 & $<1$ & 18.5 & 4.5 & 2.8 & 0.22 & - \\
\hline $15 \mathrm{E} 2$ & PV & 31.7 & 57.6 & 43.5 & -57 & -7.7 & 16 & 19.7 & 4.4 & 2.8 & 0.50 & - \\
\hline $15 \mathrm{G} 4^{\mathrm{f}}$ & PV & unk.; & 33.5 & 53.8 & -60 & -8.0 & - & - & 4.8 & 8.2 & - & 7.2 \\
\hline $15 G 5^{\mathrm{f}}$ & PV & 12.2 & 30.5 & 35.7 & -54 & -7.4 & - & - & 5.7 & 10.9 & - & - \\
\hline $15 \mathrm{~J} 2$ & PV & 33.8 & $40.8^{\mathrm{e}}$ & 45.3 & -57 & -7.6 & 4 & 17.6 & 10.9 & 5.5 & 0.85 & - \\
\hline $15 \mathrm{R} 6$ & MW & unk.; & 17.7 & 43.8 & -58 & -7.6 & - & - & 5.0 & 3.1 & 1.05 & 4.4 \\
\hline $16 \mathrm{~A} 3$ & MW & 44.2 & $73.2^{\mathrm{e}}$ & 51.8 & -57 & -7.8 & 16 & 21.6 & 5.2 & 2.9 & - & 7.3 \\
\hline $16 \mathrm{~B} 1^{\mathrm{f}}$ & PS & 42.7 & 118.9 & 10.3 & -55 & -7.8 & 18 & - & 6.8 & 12.1 & - & - \\
\hline 16B1 & PS & same & above & 21.8 & -58 & -8.2 & - & 13.0 & 5.8 & 15.5 & 0.32 & - \\
\hline $16 \mathrm{~B} 3$ & PV & 0.0 & 24.4 & 33.8 & -57 & -7.9 & - & 20.4 & 6.5 & 3.0 & 0.74 & - \\
\hline $16 \mathrm{C} 1$ & PS & 87.8 & 159.5 & 18.4 & -55 & -7.6 & - & 13.3 & 7.4 & 6.1 & 0.26 & - \\
\hline $16 \mathrm{E} 4$ & MW & 10.7 & 12.2 & 5.2 & -66 & -9.1 & $<1$ & 11.8 & 9.4 & 6.3 & 0.26 & 1.5 \\
\hline 18B1 & PS & 57.9 & 141.8 & 23.9 & -52 & -7.4 & 11 & 14.5 & 6.3 & 6.0 & 0.30 & - \\
\hline $22 \mathrm{~B} 1^{\mathrm{f}}$ & MW & 13.7 & 15.2 & 53.1 & -64 & -8.6 & $<1$ & - & 3.1 & 8.1 & - & 7.6 \\
\hline
\end{tabular}

a $\mathrm{MW}=$ monitoring well; $\mathrm{PS}=$ public supply well; $\mathrm{PV}=$ private well.

b Well depths indicated in bold are screened primarily in the Livermore Formation. All other wells are screened primarily in the alluvial layer.

c Average Errors: $\mathrm{NO}_{3}( \pm 2.7 \%), \delta^{2} \mathrm{H}_{\mathrm{H} 2 \mathrm{O}}( \pm 0.9 \%), \delta^{18} \mathrm{O}_{\mathrm{H} 2 \mathrm{O}}( \pm 0.1 \%$ o $){ }^{3} \mathrm{H}_{-}{ }^{3} \mathrm{He}$ age $( \pm 2 \mathrm{yr}), \delta^{15} \mathrm{~N}_{\mathrm{NO} 3}( \pm 0.3 \%$ o $), \delta^{18} \mathrm{O}_{\mathrm{NO} 3}$ $( \pm 0.9 \%)$, TOC $( \pm 0.3 \mathrm{mg} / \mathrm{L})$, field DO $( \pm 0.3 \mathrm{mg} / \mathrm{L})$.

d Measured at LLNL.

e Longest of multiple screens. Also screened at: 7P3 - 91.5 to $97.6 \mathrm{~m}$; 9Q1 - $38 \mathrm{~m}$ screens from 103.0 to $140.5 \mathrm{~m}$; $15 \mathrm{~J} 2-23.2$ to $24.7 \mathrm{~m} ; 16 \mathrm{~A} 3-27.7$ to $36.9 \mathrm{~m}$.

f Collected in 1/03. All other samples collected between 6/03 and 8/03. Multiple samplings at 1P2, in 6/03 and 8/03, and at $16 \mathrm{~B} 1$, in $1 / 03$ and $7 / 03$.

Table 1. Well data and chemical and isotopic analyses of samples. 